\title{
Cyanobacteria in the aquatic ecosystem of the environmental protection area (EPA) of Curiaú River, Amapá State, Amazon Region, Brazil
}

The aim of the current study is to feature the composition, frequency and richness of cyanobacteria species and their spatial-temporal distribution patterns in Curiaú River. Quarterly collections were carried out at three sampling sites, from June 2016 to October 2017. Phytoplankton and periphyton samples were collected and fixed with Transeau's solution to be identified under optical microscope. Data were statistically treated through descriptive, variance and cluster analyses significance level was set at $p<0.05$. In total, 17 taxa were identified and grouped into four (4) taxonomic orders, namely: Chroococcales, Nostocales, Synechococcales and, most prevalently, Oscillatoriales. Genera Kamptonema (67\%) and Phormidium (44\%) were the most frequent taxa. Cyanobacteria richness has shown significant variations $(p<0.05)$ among sampling sites. This pattern was not observed for seasonal fluctuations $(p>0.05)$. These data also represent pioneering information about cyanobacteria biodiversity in Amapá State.

Keywords: Cyanophyceae; Microalgae; Phytoplankton.

\section{Cianobactérias de ecossistema aquático da área de proteção ambiental (EPA) do Rio Curiaú, Estado do Amapá, Região Amazônica, Brasil}

\begin{abstract}
O objetivo do presente estudo é apresentar a composição, frequência e riqueza das espécies de cianobactérias e seus padrões de distribuição espaço-temporal no Rio Curiaú. Coletas trimestrais foram realizadas em três sítios de amostragem, de junho de 2016 a outubro de 2017. Amostras de fitoplâncton e do perifíton foram coletadas e fixadas com a solução de Transeau para a identificação taxonômica por microscopia óptica. Os dados foram tratados, estatisticamente, por meio de análises descritivas, variâncias e análise de agrupamento; o nível de significância foi em $\mathrm{p}<0,05$. No total, foram identificados 17 táxons, agrupados em quatro (4) ordens taxonômicas, os quais são: Chroococcales, Ostocales, Synechococcales e mais, prevalentemente, Oscillatoriales. Os gêneros Kamptonema (67\%) Phormidium (44\%) foram os mais frequentes. A riqueza das cianobactérias apresentou variações significativas $(p<0,05)$ entre os sítios de amostragem. Esses dados representam informações pioneiras sobre a biodiversidade de cianobactérias no Estado do Amapá
\end{abstract}

Palavras-chave: Cyanophyceae; Microalgas; Fitoplâncton.

Topic: Fundamentos de Biodiversidade

Reviewed anonymously in the process of blind peer
Received: 02/03/2021

Approved: 24/05/2021
Ademir da Silva Barros (10)

Universidade Federal do Amapá, Brasil http://lattes.cnpq.br/9203610725840775 http://orcid.org/0000-0002-7843-9756

ademirbarros41@gmail.com

Ana Carolina dos Santos Ferreira (ic)

Universidade Federal do Amapá, Brasi

http://lattes.cnpq.br/7419434786076301

http://orcid.org/0000-0003-3664-5321

aninhagahma@hotmail.com

\section{Gabriele Luini Lima Bastos}

Universidade Federal do Amapá, Brasil

http://lattes.cnpq.br/1598144612248348

http://orcid.org/0000-0002-9932-7008

gabriele.luini@gmail.com

d

DOI: 10.6008/CBPC2318-2881.2021.002.0002

\author{
Silvia Maria Mathes Faustino \\ Universidade Federal do Amapá, Brasil \\ http://lattes.cnpq.br/7743053016321109 \\ http://orcid.org/0000-0003-3216-749X \\ fitomathes@yahoo.com \\ Alan Cavalcanti da Cunha (iD \\ Universidade Federal do Amapá, Brasil \\ http://lattes.cnpq.br/2181817533284030 \\ http://orcid.org/0000-0002-1846-9486 \\ alancavalcanti@gmil.com \\ Arialdo Martins da Silveira Júnior (iD \\ Universidade Federal do Amapá, Brasil \\ http://lattes.cnpq.br/1211453646046948 \\ http://orcid.org/0000-0003-4991-210X \\ arialdomartins@gmail.com
}

Referencing this:

BARROS, A. S.; FERREIRA, A. C. S.; BASTOS, G. L. L.; FAUSTINO, S. M. M.; CUNHA, A. C.; SILVEIRA JUNIOR, A. M.. Cyanobacteria in the aquatic ecosystem of the environmental protection area (EPA) of Curiaú River, Amapá State, Amazon Region, Brazil. Nature and Conservation, v.14, n.2, p.12-21, 2021. DOI:

http://doi.org/10.6008/CBPC2318-2881.2021.002.0002 


\section{INTRODUCTION}

Cyanobacteria, also known as blue algae, are phytoplankton organisms (algae) belonging to the Bacterium domain, they form an ancestral group of microorganisms that are more than 3.5 billion years old; thus, they were the first organisms to present chlorophyll and perform photosynthesis (VIDOTTI et al., 2004). Based on the main morphological features capable of differentiating individuals within the Cyanophyceae class, Cyanophyta division presents 8 (eight) orders, namely: Gloeobacterales, Synechococcales, Spirulinales, Chroococcales, Pleurocapsales, Chroococcidiopsidales, Oscillatoriales and Nostocales (KOMÁREK et al., 2014).

Studies have shown that cyanobacteria have the ability to develop in different aquatic environments (ALMEIDA et al., 2018; BRASIL, 2003; CATHERINE et al., 2013; MARINO, 2017; SÁ et al., 2010), but freshwater environments are the ones that most favor their development, since water at $\mathrm{pH}$ ranging from 6 to 9 (neutroalcaline) at temperature ranging from $15^{\circ} \mathrm{C}$ to $30^{\circ} \mathrm{C}$, and with high concentration of nutrients such as phosphorus and nitrogen, enables the growth of these microorganisms (ALMEIDA et al., 2018; LEITE et al., 2018).

Thus, cyanobacteria can better develop in environments presenting high nutrient levels, where they can largely proliferate and develop a green layer under water, known as bloom (CHORUS et al., 1999). Physical and chemical factors, thermal stratification and turbidity decrease can have direct influence on this phenomenon (JARDIM et al., 2014).

Cyanobacteria bloom leads to environmental, social and economic impacts. This phenomenon affects the scenic quality of aquatic environments and, consequently, hinders their multiple-use alternatives, such as balneability, population supply, aquaculture and fishing, agricultural irrigation, among others (DEBERT et al., 2004). However, the risk posed to public health is one of the aggravating factors of cyanobacteria, due to poisoning resulting from the intake of water rich in secondary metabolites deriving from these microorganisms (JARDIM et al., 2014).

Given the toxicity of cyanobacteria, resolution n. 357 from March $17^{\text {th }}, 2005$ (BRASIL, 2005) has established the maximum limit for the presence of cyanobacteria in water bodies. Cyanobacteria density cannot exceed 20,000 cell./mL or $2 \mathrm{~mm}^{3} / \mathrm{L}$ in class 1 rivers; 50,000 cell./mL or $5 \mathrm{~mm}^{3} / \mathrm{L}$, in class 2 rivers; and 100,000 cell. $/ \mathrm{mL}$ or $10 \mathrm{~mm}^{3} / \mathrm{L}$, in class 3 rivers.

Nowadays, many Conservation Units (CU) in Amapá State suffer the pressure from urban progress; this is the case of the Environmental Protection Area of Curiaú River, which lies few kilometers away from downtown Macapá (State capital). Curiaú River basin is directly affected by anthropic actions, mainly because it is used for balneability and recreation on an unrestricted basis (TAKIYAMA et al., 2003).

Therefore, the aim of the present study was to feature the composition, frequency and richness of Cyoanophyceae species, as well as their spatial-temporal distribution patterns in middle Curiaú watercourse (Amazonian watercourse) belonging to Curiaú River Basin. The study can help improving the current knowledge about phytoplankton in Amapá State and, consequently,- providing data capable of supporting 
phycological studies performed in the Amazon region.

\section{MATERIALS AND METHODS}

\section{Study site}

Middle Curiaú watercourse belongs to Curiaú River basin (Figure 1), whose drainage system is interconnected to temporary and permanent lakes, that, in their turn, are influenced by the local tidal regime. The region presents dry Summer (July/December) and significantly increased water volume in Winter (January/June) (SILVA et al., 2013). Curiaú River water is mainly used for balneability, agricultural irrigation, artisanal fishing and desentation of animals bred in the region. All these use alternatives emphasize the basin's great importance for the hydrological system in the region and for the population benefiting from it.

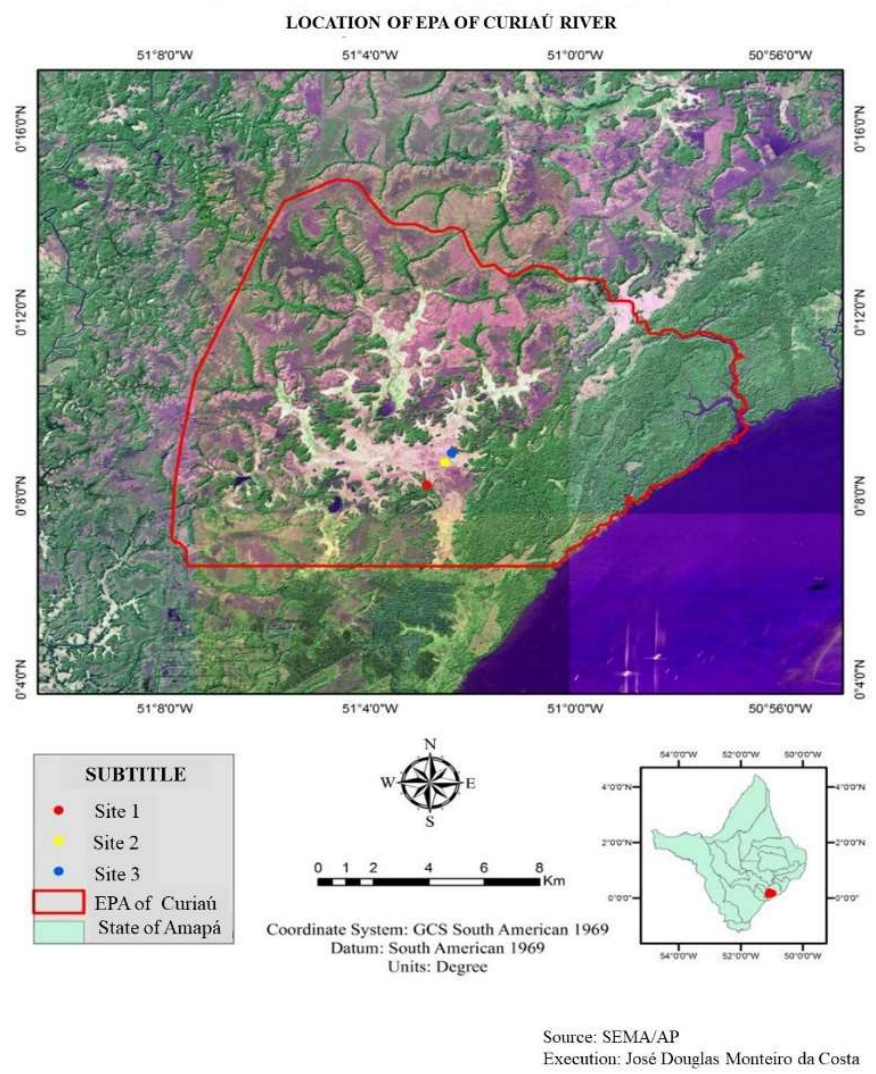

Figure 1: Map of the location of the study area and sampling site in the Curiaú River basin.

\section{Sampling periodicity, taxonomic identification and taxa occurrence frequency}

Sample collections were carried out on a quarterly basis, from June 2016 to October 2017, in order to cover the following seasonal periods: D (dry), D-R (dry-rainy transition), R (rainy) and R-D (rainy-dry transition). Three sampling sites were selected in strategic regions of Curiaú Stream to collect qualitative cyanobacteria samples.

Water samples were collected with the aid of phytoplankton net (mesh $=20 \mu \mathrm{m}$ ). The net was passed several times on the surface of the water $(25-30 \mathrm{~cm}$ deep) at collection time to obtain a reasonable amount of material. Periphyton samples were collected from squeezed roots and/or parts of submerged aquatic macrophytes (leaves and petioles) based on the scraping technique. Collected material was fixed and 
preserved with Transeau solution (BICUDO et al., 2006).

The material was subjected to taxonomic identification under optical microscope at the Environmental Sanitation Laboratory of Federal University of Amapá. The identification process was based on the existing literature and on specific identification keys (ANAGNOSTIDIS et al., 1988; ANAGNOSTIDIS et al., 1990; BICUDO et al., 2006; SANT'ANNA et al., 2012; KOMÁREK et al., 2014; BRASIL, 2015).

Taxa occurrence frequency (\%) was determined according to Mateucci and Colma (1982). Results were obtained through the following formula: $(n * 100) / N$; wherein, $n=$ number of samples presenting the investigated taxa and $\mathrm{N}$ = the total number of samples (space-time) analyzed throughout the study. In the end, taxa were classified as follows: very frequent ( $M F \geq 70 \%)$, frequent ( $F<70 \%$ and $\geq 40 \%$ ), lesser frequent ( $P F<40 \%$ and $\geq 10 \%)$ and sporadic $(E<10 \%)$.

\section{Data processing}

Data were tabulated in Excel spreadsheet and subjected to statistical analysis in the R-statistics software (R DEVELOMENT CORE TEAM, 2012). Absolute values, means, medians, standard deviation, minimum and maximum values, and coefficient of variations (\%) were calculated through descriptive analysis.

Normality test (Shapiro-Wilk) was performed to evaluate data homogeneity. Kruskal-Wallis nonparametric test ( $p>0.05)$ was applied to heterogeneous data to evaluate (seasonal space) variations in cyanobacteria incidence. Cluster analysis (hierarchical cluster) was also applied to enable visualizing similarity between samples in space and time.

\section{RESULTS}

In total, 17 cyanobacteria taxa were identified at the end of the study. Of these, 14 taxa were identified at specific level, whereas 3 were identified at genus level; they were distributed in 4 taxonomic orders (Table 2).

Most taxa belonged to order Oscillatoriales $(N=7 ; 41.18 \%)$, which was followed by Nostocales $(N=5$; 29.41\%), Synechococcales $(\mathrm{N}=3 ; 17.65 \%)$ and Chrocooccales $(\mathrm{N}=2 ; 11.76 \%)$. Order Oscillatoriales encompassed four genera, namely: Arthrospira spp., Oscillatoria spp., Kamptonema spp. and Phormidium spp. On the other hand, order Nostocales encompassed two genera - i.e., Dolichospermum spp. and Stigonema spp.

Table 1: List of identified taxa, frequency class (FC) and site of occurrence. S: sporadic; RU: relatively uncommon; RC: relatively common; D: dry; R: rainy; D-R: dry-rainy transition; R-D: rainy-dry transition

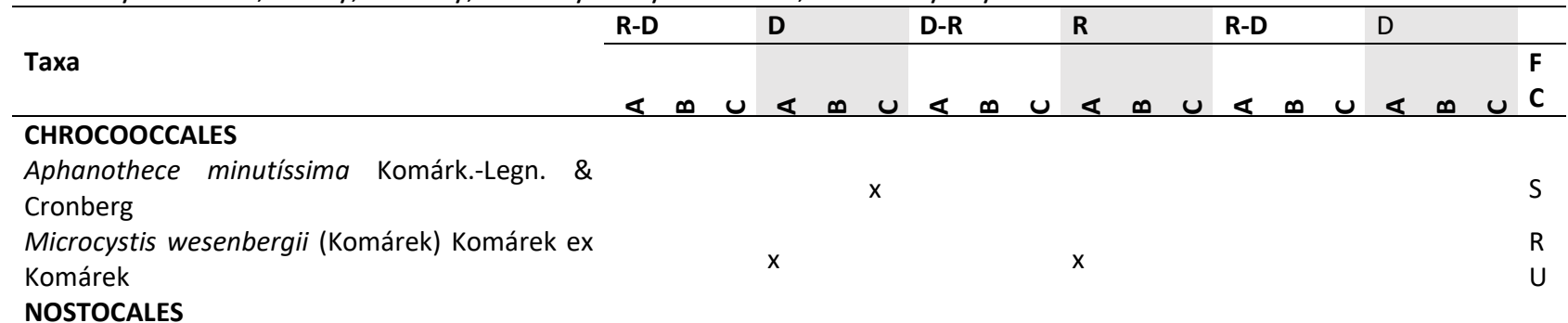


Dolichospermum circinale Rabenhorst ex Bornet

\& Flahault

$\mathrm{x}$

$\mathrm{x}$

Dolichospermum planctônicum Wacklin,

L.Hoffmann \& Komárek

Dolichospermum spiroides Wacklin, L.Hoffmann

\& Komárek

Stigonema ocellatum Thuret ex Bornet e Flahault $\mathrm{X}$

(1)

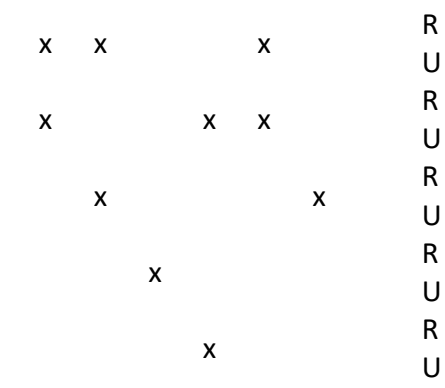

Stigonema sp. C. Agardh ex Bornet e Flahault

\section{OSCILATORIALLES}

Arthrospira platensis Gomont

Oscillatoria annae Goor

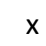

$\times \quad \mathrm{R}$

Oscillatoria limosa C. Agardh ex Gomont

Oscillatoria perornata Skuja

Oscillatoria princeps Vaucher ex Gomont

Kamptonema formosum Bory ex Gomont

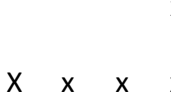

Phormidium tergestinum Rabenhorst ex Gomont $\mathrm{X} \quad \mathrm{X}$

\section{SYNECHOCOCCALES}

Aphanocapsa incerta G.Cronberg \& Komárek

Leptolyngbya sp. Anagnostidis \& Komárek

$x$

Merimospedia sp. Meyen

(1)

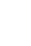

(1)


$11.7 \%(\mathrm{~N}=2)$, as relatively common ( $\mathrm{RC})$; and $5.8 \%(\mathrm{~N}=1)$, as sporadic (S) (Figure 4). Kamptonema formosum (67\%) and Phormidium tergestinum (44\%) were the taxa presenting the highest incidence frequency (Figure 5).

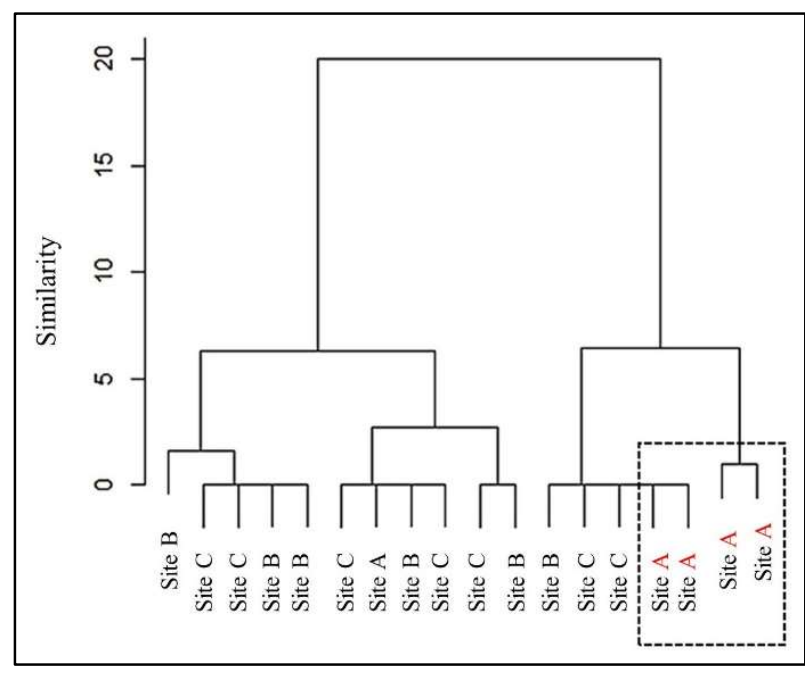

Figure 3: Association dendogram (hierarchical cluster) of cyanobacteria richness among sites and sampling periods.

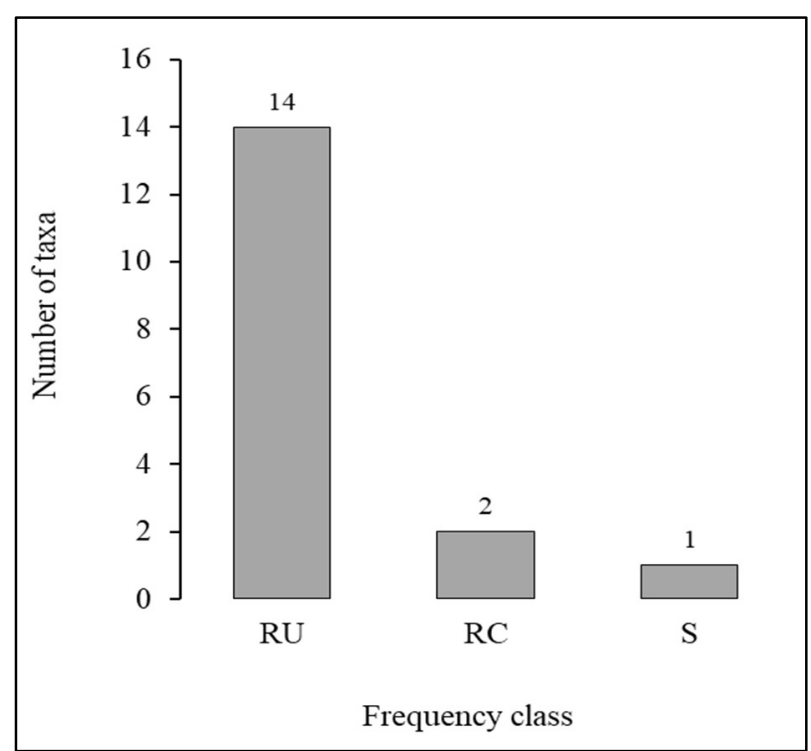

Figure 4: Distribution of taxa by frequency class. RU: relatively uncommon; RC: relatively common; S: sporadic.

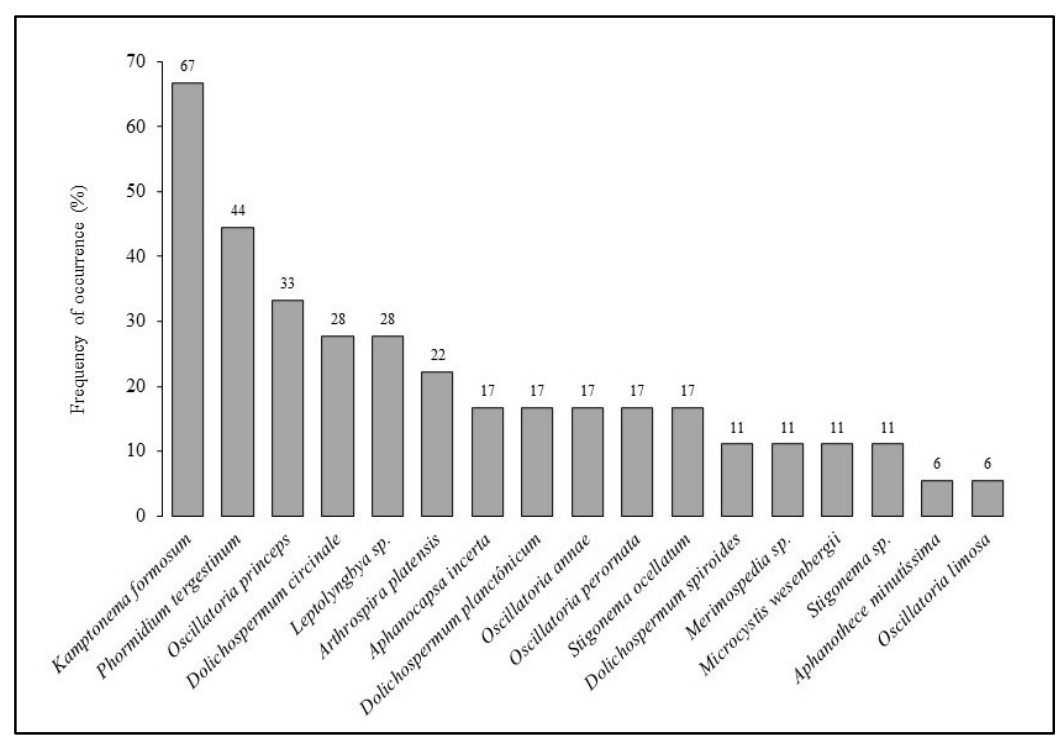

Figure 5: Frequency of occurrence of taxa identified in the study area.

\section{DISCUSSION}

Most of the identified taxa were grouped into orders of filamentous cyanobacteria, such as Oscillatoriales and Nostocales. These cyanobacteria are widely distributed among ecosystems, as reported in river environments (APRILE et al., 2007; CUNHA et al., 2013; SANTIAGO et al., 2011), estuaries (FERREIRA et al., 2004; SILVEIRA JÚNIOR, 2012), damming ecosystems (CUNHA et al., 2013; SANT'ANNA et al., 2007), springs (MAGALHÃES, 2007), and mangrove areas (BRANCO et al., 2003). Such a wide distribution emphasizes the ability of filamentous homocystous cyanobacteria to adapt to different environment types (BRANCO et al. 2003). In addition, some organisms belonging to orders Nostocales and Oscillatoriales may form perennial, 
and even dominant, populations in tropical and subtropical ecosystems (FUENTES, 2015).

The most recent studies carried out in Amapá State (DIAS, 2007; OLIVEIRA, 2007; SILVEIRA JUNIOR, 2012; CUNHA et al., 2013) have shown that cyanobacteria, as well as the Chlorophyta division (green algae), are among the microalgae groups mostly associated with phytoplankton dynamics in terms of richness. The presence of these organisms in different waterbodies is associated with a group of environmental factors such as Nitrogen and Phosphorus concentration, as well as high temperatures and light availability (KOKOCIŃSKI et al., 2010; SÁ et al., 2010). In addition, cyanobacteria present chromatic adaptation type and it enables their prevalence under different environmental conditions, regardless of the luminosity level (TONETTO et al., 2018). Some filamentous cyanobacteria are photoadaptive, common to shallow lakes and exposed to wind (KOKOCIŃSKI et al., 2010). These factors may be causally linked to their spatial-temporal distribution in natural environments.

The spatial-seasonal fluctuations of cyanobacteria in Curiaú Stream have shown significant variations along the sampling sites; the largest number of taxa was associated with site A. Samples collected in this site were mostly grouped by cluster analysis dendrogram (Figure 3), which showed the dissimilarity between site A and the other sampling sites.

The presence of macrophytes on riverbanks or floating on water surface during the low rainfall period (dry) was remarkable at site A. This phenomenon allowed collecting qualitative samples with high organic matter concentrations and macrophyte debris, such as Eichhornia crassipes and Pistia stratiotes, which are often seen in the study site (POMPÊO, 2017).

Cyanobacteria often coexist with aquatic plant debris and organic components (MOSCHINI-CARLOS, 1999; PEINADOR, 1999). Some important genera such as Phormidium, Aphanizomenon and Dolichospermum are often found in freshwater environments rich in macrophytes (SANTOS et al., 2010). All genera, except for Aphanizomenon, were inventoried in Curiaú Stream and expressed the pattern previously reported in the literature.

In addition, site A presented different hydrological features; it was strongly influenced by dry season, since the significant drop in its water volume had direct impact on its limnetic flow. Dry periods, in their turn, have led to low water flow rate (JARDIM et al., 2014), which changed the dynamics of the stream. This phenomenon has influenced the different richness rates observed between collection sites, mainly during the dry season.

Kamptonema formosum and Phormidium tergestinum were the taxa presenting the highest incidence frequency. Both belong to order Oscillatoriales, which is common in Brazil (BICUDO et al., 2006). This order can be found in environments subjected to extreme conditions, such as polar, desert and thermal environments (MALONE et al., 2012), a fact that emphasizes its high adaptability and frequency - it has approximately 200 species distributed worldwide (BICUDO et al., 2006).

The great adaptability of order Oscillatoriales was also described in studies conducted in saline water (FERNÁNDEZ, 2014) and transition zones presenting strong limnetic flow (KOMÁREK et al., 2005; KOMÁREK, 2013). These cyanobacteria present ecological advantages capable of overcoming some environmental 
limitations (TONETTO et al., 2018), a fact that corroborates their incidence in different landscapes.

Of the total taxa identified in the current study, six genera (29.4\%) were reported in the literature as potentially toxic, namely: Aphanocapsa, Dolichospermum, Kamptonema, Microcystis, Oscillatoria and Phormidium (CARVALHO et al., 2013, BORTOLI et al., 2015). It means that under ideal conditions, these genera can develop bloom and have harmful effects on both the ecosystem and on its multiple uses.

Genera Kamptonema and Oscillatoria, which recorded $68 \%$ and $33 \%$ incidence in the current study, respectively, are among the main groups of potentially toxic cyanobacteria found in Brazil (BRASIL, 2003). More than 20 species of potentially toxic cyanobacteria have been recorded in the country; they belong to 14 genera found in different regions countrywide (SANT'ANNA et al., 2000).

Other genera often recorded in flowering processes observed in Brazil were also found in the current study, namely: Dolichospermum (28\%) and Microcystis (11\%). These genera are mentioned in the literature as producers of different toxin groups such as Microcystin, Antoxin-a (S), Anatoxin-a and Saxitoxins-a (S) (PICCIN-SANTOS et al., 2012). These toxins can have extremely harmful effects on both animals and humans (CARVALHO et al., 2013), which may hinder the use of water resources for different purposes, such as recreation - one of the main activities developed in Curiaú River region.

\section{CONCLUSIONS}

Cyanobacteria composition follows the pattern observed in other Brazilian ecosystems, i.e., it presented prevalence of filamentous organisms. Sampling site location has influenced species richness; the highest incidence of it was associated with areas presenting different hydrological features, greater macrophyte presence and greater proximity to the urban conglomerate. These factors may have influenced cyanobacteria development due to domestic waste discharge, although it was not the focus of the current study. In addition, potentially toxic taxa previously described in the literature were also identified in the present study, besides the frequent species in the study site. Finally, the herein collected data are essential to help improving knowledge about the Amazonian biodiversity, mainly about the incidence of cyanobacteria in Amapá State.

\section{REFERENCES}

ANAGNOSTIDIS, K.; KOMÁREK, J.. Modern approach to the classification system of Cyanophyta: Oscillatoriales. Algological Studies, v.80, p.327-472, 1988

ANAGNOSTIDIS, K.; KOMÁREK, J.. Modern approach to the classification system of Cyanophyta: Stigonematales. Algological Studies, v.80, p.01-73, 1990.

ALMEIDA, J. M.; AMÉRICO-PINHEIRO, J. H. P.. Efeitos de cianobactérias tóxicas em ambientes aquáticos. Fórum Ambiental da Alta Paulista, v.14, n.2, p.142-154, 2018. DOI: http://dx.doi.org/10.17271/1980082714220181926

APRILE, F. M.; MERA, P. A. S.. Fitoplâncton e fitoperifiton de um rio de águas pretas da Amazônia periférica do norte, Brasil. Brazilian Journal of Aquatic Science and Technology, v.11, n.2, p.1-14, 2007. DOI:

https://doi.org/10.14210/bjast.v11n2.p1-14

BICUDO, C. E. M.; MENEZES, M.. Gêneros de algas de águas continentais do Brasil: chave para identificação e descrições. São Carlos: Rima, 2006

BORTOLI, S.; PINTO, E.. Cianotoxinas: características gerais, histórico, legislação e métodos de análises. In: Ecologia de reservatórios e interfaces. São Paulo, 2015. p.321-339.

BRANCO, L. H. Z.; MOURA, A. N.; SILVA, A. C.; BITTENCOURTOLIVEIRA, M. C.. Biodiversidade e considerações biogeográficas das Cyanobacteria de uma área de Manguezal do Estado de Pernambuco, Brasil. Acta Botanica 
Brasilica, v.17, n.4, p.585-596, 2003. DOI: http://dx.doi.org/10.1590/S0102-33062003000400010

BRASIL. Ministério da Saúde. Cianobactérias/cianotoxinas procedimentos de coleta, preservação e análise. Brasília: MS, 2015

BRASIL. Ministério da Saúde. Cianobactérias Tóxicas na Água para Consumo Humano na Sáude Pública e Processos de Remoção em Água para Consumo Humano. Brasília: MS, 2003.

BRASIL. Conselho Nacional do Meio Ambiente. Resolução n.357, de 17 de março de 2005. Dispõe sobre a classificação dos corpos de água e diretrizes ambientais para o seu enquadramento, bem como estabelece as condições e padrões de lançamento de efluentes, e dá outras providências. Brasília: DOU, 2005.

CARVALHO, M. C.; AGUJARO, L. F.; PIRES, D. M.; PICOLE, C. Manual de Cianobactérias Planctônicas: legislação, Orientações para o Monitoramento e Aspectos Ambientais. São Paulo: Companhia Ambiental do Estado de São Paulo, 2013.

CATHERINE, Q.; SUSANNA, W.; ISIDORA, E.-S.; MARK, H.; AURÉLIE, V.; JEAN-FRANÇOIS, H.. A review of current knowledge on toxic benthic freshwater cyanobacteria Ecology, toxin production and risk management. Water Research, v.47, n.15, p.5464-5479, 2013. DOI: https://doi.org/10.1016/j.watres.2013.06.042

CHORUS, I.; BARTRAM, J.. Toxic Cyanobacteria in Water: A guide to their public health consequences, monitoring and management. Londres, 1999.

CUNHA, E. D. S.; CUNHA, A. C.; SILVEIRA JUNIOR, A. M.; FAUSTINO, S. M. M.. Phytoplankton of two rivers in the eastern Amazon: characterization of biodiversity and new occurrences. Acta Botanica Brasilica, v.27, n.2, p.364-377, 2013. DOI: https://doi.org/10.1590/S010233062013000200011

DEBERT, G. L. B.; CANTUSIO NETO, R.; AGUJARO, L. F.. Florações de cianobactérias e sua inserção na legislação brasileira. Brasília: Ministério da Saúde, 2004.

DIAS, M. B.. Composição e abundância do fitoplâncton do sudoeste da Reserva Biológica do Lago Piratuba (Amapá, Brasil). Dissertação (Mestrado) - Universidade Federal do Amazonas, Manaus, 2007

FERNÁNDEZ, M. E. G.. Biodiversidade de macroalgas contonentales y evaluación de la calidad da ecológica en aguas de transición. El caso del marjal de Pego-Oliva (E de la península Ibérica). Universidade de Murcia, 2014.

FERREIRA, A. H. F.; MINILLO, A.; SILVA, L. M.; YUNES, J. S. Ocorrência de Anabaena spiroides (Cianobactéria) no estuário da Lagoa dos Patos (RS, Brasil) no verao-outono de 1998. Atlântica, v.26, p.17-26, 2004. DOI:

https://doi.org/10.5088/atlântica.v26i1.2229

FUENTES, E. V.. Ecologia do fitoplâncton na Lagoa do Peri: influência da variabilidade climática sobre a limnologia e a dinâmica de cianobactérias. Tese (Doutorado) - Universidade Federal de Santa Catarina, Florianópolis, 2015.
JARDIM, F. A.; VON SPERLING, E.; JARDIM, B. F. M.; ALMEIDA, K. C. B.. Fatores determinantes das florações de cianobactérias na água do Rio Doce, Minas Gerais, Brasil. Engenharia Sanitaria e Ambiental, v.19, n.3, p.207-218, 2014. DOI: https://doi.org/10.1590/S1413$\underline{41522014019000001026}$

KOKOCIŃSKI, M.; STEFANIAK, K.; MANKIEWICZ-BOCZEK, J.; IZYDORCZYK, K.; SOININEN, J.. The ecology of the invasive cyanobacterium Cylindrospermopsis raciborskii (Nostocales, Cyanophyta) in two hypereutrophic lakes dominated by Planktothrix agardhii (Oscillatoriales, Cyanophyta). European Journal of Phycology, v.45, n.4, p.365-374, 2010. DOI: https://doi.org/10.1080/09670262.2010.492916

KOMÁREK, J.. Cyanoprocaryota 19/3: Heterocystous genera. Süßwasserflora von Mitteleuropa. Heidelberg: Springer Spektrum, 2013.

KOMÁREK, J.; ANAGNOSTIDIS, K.. Cyanoprocaryota 19/02: Oscillatoriales. In: BÜDEL, B.; GARTNER, G.; KRIENTZ, L.; SCHARGEL, M.. Süßwasserflora von Mitteleuropa. Heidelberg: Elsevier, Spektrum Akademischer Verlag, 2005.

KOMÁREK, J.; KASTOVSKY, J.; MARES, J.; JOHANSEN, J. R.. Taxonomic classification of cyanoprokaryotes (cyanobacterial genera) 2014, using a polyphasic approach. Preslia, v.6, n.2, p.103-126, 2014.

LEITE, A. R. C.; BIAGIONI, R. C.; SMITH, W. S.. Diversidade de cianobactérias em mananciais da bacia do rio Sorocaba, com ênfase nas represas de Itupararanga e Ipaneminha, SP, Brasil. Revista Brasileira de Biociências, v.16, n.1, p.11-20, 2018.

MAGALHÃES, A. B. S.. Ocorrência de cianobactérias em mananciais de abastecimento de água para consumo humano no município de Viçosa - MG. Dissertação (Mestrado) - Universidade Federal de Viçosa, 2007.

MALONE, C. F. S.; SANTOS, K. R. S.; SANT'ANNA, C. L.. Algas e cianobactérias de ambientes extremos do pantanal brasileiro. Oecologia Australis, v.16, n.04, p.745-755, 2012.

MARINO, L.. Relação entre clorofila-a e cianobactérias no estado de São Paulo. Revista DAE, v.65, n.206, p.32-43, 2017. DOI: http://doi.org/10.4322/dae.2016.026

MOSCHINI-CARLOS, V.. Importância, estrutura e dinâmica da comunidade perifítica nos ecossistemas aquáticos continentais. In: POMPÊO, M. L. M.. Perspectivas na Limnologia no Brasil. 1999. p.1-11.

OLIVEIRA, J. E.. Caracterização da comunidade potamofitoplanctônica da bacia do rio Araguari (AP) nos períodos de seca e chuva (2004, 2005 e 2006). Dissertação (Mestrado) - Universidade Federal de Góais, Goiânia, 2007.

PEINADOR, M.. Las cianobacterias como indicadores de contaminación orgánica. Revista de Biologia Tropical, v.47, n.3, p.381-391, 1999.

PICCIN-SANTOS, V.; BITTENCOURT-OLIVEIRA, M. C.. Toxic Cyanobacteria in Four Brazilian Water Supply Reservoirs. Journal of Environmental Protection, v.03, n.01, p.68-73, 2012. DOI: http://dx.doi.org/10.4236/jep.2012.31009 
POMPÊO, M.. Monitoramento e manejo de macrófitas aquáticas em reservatório tropicais brasileiros. São Paulo: Universidade de São Paulo, 2017.

SÁ, L. L. C.; VIEIRA, J. M. S.; MENDES, R. A.; PINHEIRO, S. C. C.; VALE, E. R.; ALVES, F. A. S.; JESUS, I. M.; SANTOS, E. C. O.; COSTA, V. B.. Ocorrência de uma floração de cianobactérias tóxicas na margem direita do rio Tapajós, no Município de Santarém (Pará, Brasil). Revista Pan-Amazônica de Saúde, v.1, n.3, p.69-74, 2010. DOI:

http://dx.doi.org/10.5123/S2176-62232010000100022

SANT'ANNA, C. L.; AZEVEDO, M. T. P.. Contribution to the knowledge of potentially toxic cyanobacteria from Brazil. Nova Hedwigia, v.3, n.4, p.359-385, 2000.

SANT'ANNA, C.; TUCCI, A.; AZEVEDO, M. T.; MELCHER, S.; WERNER, V.; MALONE, C.; ROSSINI, E.; JACINAVICIUS, F.; HENTSCHKE, G.; OSTI, J. A.; SANTOS, K. R.; DAMA JUNIOR, W.; ROSAL, C.; ADAME, G.. Atlas de cianobactérias e microalgas de águas continentais brasileiras. São Paulo: Instituto de Botânica, 2012.

SANT'ANNA, C. L.; MELCHER, S. S.; CARVALHO, M. D. C.; GELMEGO, M. P.; AZEVEDO, M. T. D. P.. Planktic Cyanobacteria from upper Tietê basin reservoirs, SP, Brazil. Revista Brasileira de Botânica, v.30, n.1, p.1-17, mar. 2007. DOI: http://dx.doi.org/10.1590/S0100-84042007000100002

SANTIAGO, R. T.; KEPPELER, E. C.. Fitoplâncton de um trecho do rio Japiim em Mâncio Lima-AC. Ensaios e Ciência:

Ciências Biológicas, Agrárias e da Saúde, v.15, n.5, p.93-100, 2011. DOI: https://doi.org/10.17921/1415-

6938.2011v15n5p\%25p
SANTOS, K. R. S.; SANT'ANNA, C. L.. Cianobactérias de diferentes tipos de lagoas ("salina", "salitrada" e "baía") representativas do Pantanal da Nhecolândia, MS, Brasil. Brazilian Journal of Botany, v.33, n.1, p.61-83, 2010. DOI: http://dx.doi.org/10.1590/S0100-84042010000100007

SILVA, R. B. L.; FREITAS, J. L.; SANTOS, J. U. M.; SOUTO, R. N. P.. Caracterização Agroecológica e Socioeconômica dos Moradores da Comunidade Quilombola do Curiaú, MacapáAP, Brasil. Biota Amazônia, v.3, n.3, p.113-138, 2013. DOI: http://dx.doi.org/10.18561/21795746/biotaamazonia.v3n3p113-138

SILVEIRA JÚNIOR, A. M.. Composição e biomassa microfitoplanctônica associada a variáveis físico e químicas em dois transectos da zona estuarina do Rio Amazonas (Amapá, Amazônia, Brasil). Dissertação (Mestrado) Universidade Federal do Amapá, Macapá, 2012.

TAKIYAMA, L. R.; SILVA, A. Q.; COSTA, W. J. P.; NASCIMENTO, H. S.. Qualidade das Águas das Ressacas das Bacias do Igarapé da Fortaleza e do Rio Curiaú. In: TAKIYAMA, L. R.; SILVA, A. Q.. Diagnóstico das ressacas do estado do Amapá: bacias do Igarapé Fortaleza e Rio Curiaú. 2003. p.81-104.

TONETTO, A. F.; AURICCHIO, M. R.; PEZZATTO, L. C.; PERES, C. K.. Macroalgas de riachos na Serra do Japi, sudeste do Estado de São Paulo, Brasil. Hoehnea, v.45, n.4, p.616-628, 2018. DOI: https://doi.org/10.1590/2236-8906-37/2018

VIDOTTI, E. C.; ROLLEMBERG, M. D. C. E.. Algas: da economia nos ambientes aquáticos à bioremediação e à química analítica. Química Nova, v.27, n.1, p.139-145, 2004. DOI: https://doi.org/10.1590/S0100-40422004000100024

A CBPC - Companhia Brasileira de Produção Científica (CNPJ: 11.221.422/0001-03) detém os direitos materiais desta publicação. Os direitos referem-se à publicação do trabalho em qualquer parte do mundo, incluindo os direitos às renovações, expansões e disseminações da contribuição, bem como outros direitos subsidiários. Todos os trabalhos publicados eletronicamente poderão posteriormente ser publicados em coletâneas impressas sob coordenação da Sustenere Publishing, da Companhia Brasileira de Produção Científica e seus parceiros autorizados. Os (as) autores (as) preservam os direitos autorais, mas não têm permissão para a publicação da contribuição em outro meio, impresso ou digital, em português ou em tradução. 